\title{
Выбор параметров скважинной гидродобычи на железорудных месторождениях Южной Якутии
}

\author{
Шестаков В.С., студент, \\ Технический институт (филиал) \\ Северо-Восточного федерального университета, \\ 2. Нерюнгри \\ E-mail: light.inc@yandex.ru
}

Научный руководитель: к.т.н., доцент Рочев В.Ф.

Скважинная гидродобыча (СГД) является одной из физико-химических геотехнологий, осуществляемых через скважины с помощью гидравлической энергии, используемой для разрушения горных пород, доставки разрушенных пород к скважине и подъема их на поверхность.

При скважинной гидродобыче технологические процессы разрушения горной массы, пульпо-приготовления, всасывания и гидроподъема осуществляются с помощью напорного потока воды через скважины небольшого диаметра. Технология реализуется следующим образом: в пробуренную и обсаженную скважину опускают специальный гидромонитор и гидроподъемное устройство. При этом массив породы разрушается гидромониторной струей жидкости, а выдача образовавшейся после размыва гидросмеси в очистной камере осуществляется эрлифтом либо эжектором (гидроэлеватором) на поверхность. Скважинная гидротехнология включает в себя множественные процессы.

Эти технологические процессы тесно взаимосвязаны между собой и в своей совокупности представляют решение сложной задачи - совмещение разноструктурных процессов в единый технологический цикл добычи полезных ископаемых через скважины с учетом различных горно-геологических требований к процессу гидродобычи.

Целью я предлагаю разработку железорудного месторождения. В качестве примера я выбрал Таежное месторождение

Залежи железных руд Таежного месторождения локализованы в леглиерском продуктивном горизонте мощностью 320 м. В составе горизонта выделены три пачки: нижняя рудная (120-200 м), гнейсовая межрудная (40-80 м), и верхняя рудная (до 120 м). В нижней части рудной пачки находится главная рудная залежь. 


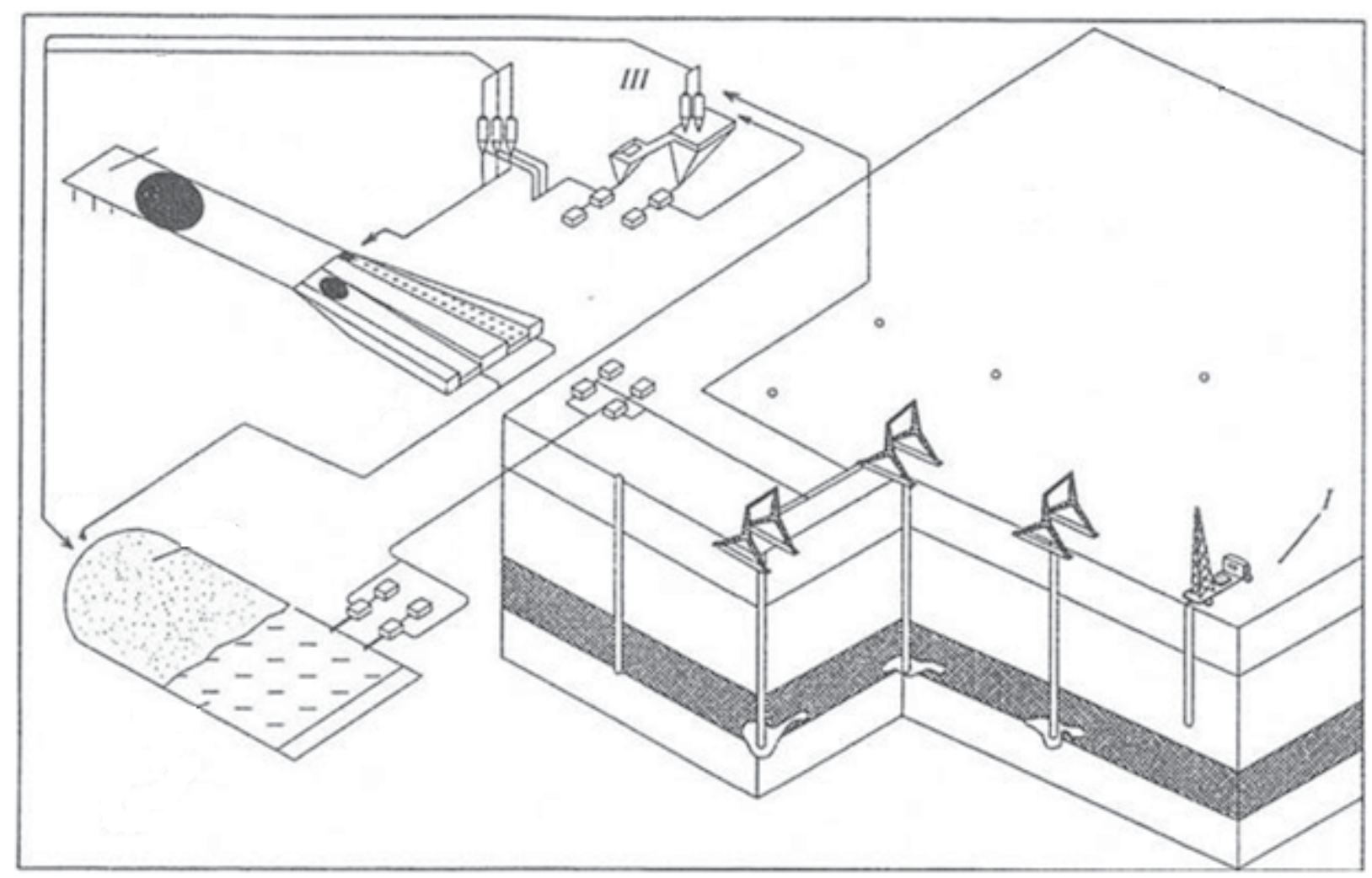

Рис. 1. Схема скважинной гидродобычи для железной руды I- участок скважинной гидродобычи; III — участок обогащения

При вскрытии пласта бурятся разведочные скважины глубиной 1200 метров, затем производится расширение данной скважины до эксплуатационного диаметра(300мм). После устанавливается обсадная труба, затем производится применение торпедирования для улучшения трещиноватости для последующего размыва. После торпедирования устанавливаются оборудования для размыва железной руды (гидромонитор) и подъема железной руды (трубы).

Обсадная труба - 286 мм; труба алюминиевые для подъёма руды - 140 мм.

Сущность способа заключается в отработке рудного залежи снизу в верх отдельными горизонтальными слоями (ступени). После образования гидровруба на первой ступени водоподающую колонну труб поднимают до отметки верхней границы второй ступени, а рудоподъемную - на высоту, обеспечивающую возможность получения чистых руд. При этом систематически подают жидкий нерастворитель (для поддержания кровли).

Расчеты

Мощность пласта вскрышных пород: 600

Мощность железорудного пласта: 35

Будет задействовано 3 буровых станков типа УРБ 2a2

Балансовый запас: 1255 млн. т со средним содержанием железа 39,5\%

Глубина скважины: 600 м

Диаметр обсадной трубы:286 мм

Диаметр подъемной трубы: 140 мм

Диаметр транспортируемой трубы: 113 мм

Объём руды в 1й скважине: 11835,7 м ${ }^{3}$ 
За сутки качаем руду: 3945,2 м $^{3}$

За смену качаем руды: 1972,6 м ${ }^{3}$

За час качаем руду: 164,3 м

Марка компрессора: XAC47

Производительность компрессора: от 1,6 до 5 м³/мин

Марка насоса: Grundfos серии CR

Производительность насоса: до $180 \mathrm{~m}^{3} / \mathrm{ч}$

Объем двух зумпфов: 216 м $^{3}$

Скважина на воду: 219 мм

Количество скважин: 60 шт

Расстояния между скважинами 40 м

Взрывчатое вещество: микро взрывы аммиачная селитра

Объем воды: $180 \mathrm{~m}^{3} / ч$

Давления воды на насадки: 3 мПа

Давления воды на забои: 0,6 мПа

Диаметр насадки гидромонитора: 20 мм

Насос добавочный: 8НДв

Диаметр: 60 мм

Данные значения вычисляются по формулам:

При расчете параметров эрлифта определяют расход воздуха на подъем гидросмеси

$$
Q_{\text {возд }}=\frac{Q_{\Gamma} \times H \times \gamma_{\text {возд }}}{1380 \times \gamma_{\Gamma} \times \eta \times \operatorname{Ig}(0.1 \times h+1)}
$$

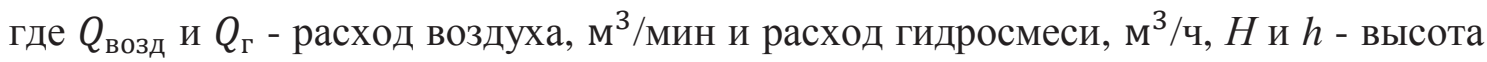
подъема и гидростатический уровень воды над воздушной форсункой эрлифта, $M, \gamma_{\Gamma}$ и $\gamma_{\text {возд }}$ - плотность воды и гидросмеси, т/ $\mathrm{M}^{3}, \eta$ - К.П.д. эрлифта

Диаметр пульпоподъемной $\left(D_{\text {эр }}\right)$ трубы определяется по формуле

$$
D_{\text {эрл }}=\left(\frac{Q_{\mathrm{r}}}{k \alpha}\right)^{0.4}
$$

(При значениях $\alpha=0,2-0,45$, коэффициент $k=0,24$. Основными характеристиками гидроэлеваторного снаряда является коэффициент эжекции (расхода) $\alpha . Q_{\Gamma}$ - расход эжектируемой гидросмеси)

Транспортирование производится гидротранспортом

Транспортирование производится гидротранспортом обеспечивает непрерывный грузопоток; исключает трудоемкие погрузо-разгрузочные работы; снижает трудовые затраты при эксплуатации; уменьшает воздействие на окружающую среду.

В данном случае более экономичными, выгодными с технологической точки зрения являются пластиковые трубы ПВХ. (толщина 12мм, d=210мм).

Обладают отличной прочностью к внешнему давлению; благодаря модульному соединению существенно упрощается процесс монтажа; устойчивость к химическому и бактериологическому загрязнению;

Инновации и преимущества

Транспортировка трубопроводом;

Отсутствие шламов на поверхность;

Безопасность; 
Без вреда для экологии;

Социальная программа по обеспечению трудоустройства местных жителей;

Экономические показатели СГД

Скважинная гидродобыча в сравнении с открытым способом имеет высокую производительность предприятия (примерно в четыре раза выше), а удельные капитальные затраты меньше почти в 5 раз.

Структура капитальных затрат и себестоимости при СГД

Себестоимость $1 \mathrm{~m} 3$

Себестоимость: СГД - 93 рублей за 1 м3 пи

$$
\text { ОГР - } 469 \text { рублей за } 1 \text { м3 пи }
$$

Прибыль при СГД:

Себестоимость ОГР(469) - Себестоимость СГД(93) = 376 руб.

$522,1+376=898,1 \mathrm{py} \sigma / \mathrm{M}^{3}$

В Якутии такие работы не ведутся. В Южной Якутии есть благоприятные участки для СГД - например, месторождение Таежное. Для внедрения данной технологии в жизнь необходимо сделаны лабораторные и необходимо сделать натурные испытания. На данный момент ведутся расчеты применительно натуральных условий к экспериментальным для СГД.

\title{
Содержание карты инженерно-геокриологического районирования территории Республики Саха (Якутия)
}

\author{
Спектор В.Б. ${ }^{1}$, д.г.-м.н., Шестакова А.А. ${ }^{1,2}$, к.г.н., Торговкин Я.И. ${ }^{1}$, к.г.н. \\ 1 - Институт мерзлотоведения им. П.И. Мельникова СО РАН, \\ 2. Якутск, \\ E-mail: mpi@ysn.ru \\ 2 - Северо-Восточный федеральный университет, \\ 2. Якутск, \\ E-mail: aashest@mail.ru
}

Под инженерно-геокриологическим районированием понимается пространственная оценка территории с точки зрения изменчивости инженерногеокриологических условий. Инженерно-геокриологические условия определяются свойствами мерзлых и оттаивающих пород, развитием мерзлотно-геологических процессов, состоянием горизонтов межмерзлотных и подмерзлотных вод, быстрой временной изменчивостью температурного поля пород [4]. Актуальность выполнения данной работы связана с ускорением освоения северных (в том числе Арктических) территорий.

Карта инженерно-геокриологического районирования территории $\mathrm{PC}$ (Я) масштаба 1:1500000 была составлена в электронном варианте в формате «ArcGIS 10 version 10.1» (рис. 1) и предназначена для комплексной оценки и использования территории Республики по размещению объектов строительства и направлениям магистральных, транспортных и инженерных коммуникаций, a также для предотвращения и защиты территории от опасных геологических процессов. Карта построена на основе анализа и обобщения основных факторов формирования инженерно-геокриологических условий на территории Республики, каковыми являются 